\title{
RELASI KUASA DALAM PRAKTIK SUKUR BUMI
}

\author{
Yanti Heriyawati \\ Jurusan Teater STSI Bandung \\ Email: heriyawati@yahoo.com \\ Soebakdi Soemanto \\ Fakultas Ilmu Budaya Universitas Gadjah Mada
}

Heru Nugroho

Fakultas Ilmu Sosial dan Ilmu Politik Universitas Gadjah Mada

\begin{abstract}
This article is a study on the form of power relations in Sukur Bumi as a cultural practice. Sukur Bumi is a sacred ritual activity conducted by the people in Rancakalong in gratitude for their harvest. Power, in this context, is not only authority and hegemony, but also symbolic power. The power has the capability to construct knowledge and truth. Three levels of power relationships can be identified, that is, between the society and Sukur Bumi, the government and the society, and between the society, Sukur Bumi, and the government. In the end, Sukur Bumi has its own power. Its meaning and symbols have the power to control society and the government. Without Sukur Bumi, both the government and the society would not have a sphere in which they can construct power.
\end{abstract}

Keywords: Sukur Bumi, Power, Ritual, Society, Government.

\begin{abstract}
ABSTRAK
Kajian ini tentang bentuk relasi kuasa pada sukur bumi sebagai sebuah praktik kebudayaan.Sukur bumi dimaksudkan sebagai sebuah aktivitas upacara sakral yang dilakukan masyarakat Rancakalong sebagai wujud ekspresi ucap sukur atas hasil bumi.Kekuasaan tidak saja dimaknai sebagai otoritas dan hegemoni, tetapi juga sebagai kuasa simbolik. Kekuasaan punya kuasa dalam mengkontruksi pengetahuan dan kebenaran.Hubungan kekuasaan tersebut berada dalam tiga level, yakni antara masyarakat dengan sukur bumi, pemerintah dengan masyarakat, dan antara masyarakat-sukur bumi- pemerintah.Pada akhirnya, sukur bumi memiliki kuasanya sendiri.Makna dan simbol yang dimilikinya memiliki kuasa dalam mengatur masyarakat dan pemerintah.Tanpa sukur bumi, keduanya tidak memiliki ruang dalam mengkonstruksi kekuasaannya.
\end{abstract}

Kata kunci: Sukur Bumi, Kekuasaan, Upacara, Masyarakat, Pemerintah 


\section{PENGANTAR}

Makna, nilai, dan kebenaran dari sebuah praktik kebudayaan, seperti dinding transparan yang dikonstruksi oleh kekuasaan.Ia merupakan hasil dari sebuah relasi kuasa. Praktik kebudayaan merupakan arena perebutan kekuasaan. Mana pihak yang paling dominan dan siapa yang dimarjinalkan.Kemenangan dalam mempertahankan kekuasa-nya lah yang mampu membentuk dunia. Oleh karenanya, salah satu argumen utama Cultural Studies adalah bahwa kebudayaan sebagai objek studi, merupakan zona perebutan dimana makna dan versi dunia yang saling bersaing harus bertarung agar dianut dan memperoleh klaim pragmatis kebenaran. Makna dan kebenaran tersebut dibentuk dalam polapola kekuasaan. (Chris Barker, 2000: 372)

Sukur bumi adalah ritual-ritual atau upacara-upacara yang dilakukan masyarakat sebagai bentuk ucap sukur atas hasil bumi.Sukur bumi di Rancakalong merupakan peristiwa budaya yang di dalamnya terdapat pelaku dan benda-benda budaya.Artefak yang tidak diam, terus tumbuh bersama masyarakatnya.Ia sebagai warisan budaya yang masih direproduksi oleh setiap generasinya. Secara bersamaan direkonstruksi juga oleh pemerintah. Artinya masyarakat melakukan reproduksi dari apa yang telah dilakukan oleh leluhurnya, sementara pemerintah melakukan rekonstruksi dari apa yang sedang dilakukan oleh masyarakat.Dalam praktiknya, proses pemaknaan atau konstruksi nilai dalam reproduksi dan rekonstruksi disinyalir memiliki jaringan relasi kekuasaan, karena kekuasaan salah satunya merupakan suatu model komunikasi yang berbentuk simbol. Dalam hal iniproses reproduksi dihadapkan pada suatu hubungan masyarakat dengan benda budaya (sukur bumi), yang diwariskan dalam bentuk simbol-simbol, sementara dalam proses rekonstruksi pemerintah berhubungan langsung dengan masyarakat sebagai pelaku upacara dan simbol-simbol upacara. Reproduksi dan rekonstruksi sukur bumi sebagai tempat relasi kuasa bekerja.
Jika sukur bumi merupakan tempat berlangsungnya relasi kuasa, maka tentunya memiliki tingkatan atau level model relasi kuasa, baik pada reproduksi maupun pada rekonstruksinya. Sukur bumi memiliki lapisan simbol yang tebal, maknanya saling terhubung satu sama lain. Sebagai karya manusia, sukur bumi menempati tempat penting bagi masyarakatnya sekaligus pemerintah.Sehingga yang menjadi perhatian utama dalam kajian di sini adalah bagaimama relasi kuasa bekerja dalam sukur bumi.Relasi tersebut ditelusuri antara pemerintah dan masyarakat; individu dalam kelompok masyarakat, masyarakat dengan sukur bumi, atau pemerintah dengan sukur bumi, atau antara pemerintah - masyarakat - sukur bumi.

Kajian mengenai kekuasaan telah dilakukan oleh beberapa peneliti diantaranya: Benedict R. O'G. Anderson (1990), melakukan penelitian tentang bahasa dan kekuasaan Jawa di Indonesia kaitannya dengan kesadaran nasional. Hasil penelitian diwujudkan dalam sebuah buku dengan judul Language and Power: Exploring Political Cultures in Indonesia. Buku ini mengkaji lebih dalam tentang interaksi antara gagasan modernitas dan tradisi dari kekuasaan; mediasi kekuasaan oleh bahasa; dan perkembangan kesadaran nasional. Dijelaskan bagaimana bayangan tentang kekuasaan dalam tradisi masyarakat Jawa yang membentuk politik Indonesia modern. Politik dalam tradisi Jawa lebih menekankan kepada tanda-tanda konsentrasi kekuasaan, bukan demonstrasi penggunaan kekuasaan. Pertanda yang jelas sebuah kekuasaan seseorang adalah kemampuannya memfokuskan inner power untuk menyerap kekuatan dari luar dan dikonsentrasikan melalui dirinya. Seseorang yang berkuasa harus mempunyai objek-objek atau orangorang yang mengelilinginya. Selama bendabenda dan orang-orang tersebut berada dalam istana, maka kekuasaannya terserap oleh si penguasa itu.

Pierre Bourdieu (1989) dalam Social Space and Symbolic Power, dijelaskan, bahwa 
dunia sosial adalah produk dari struktur ganda: pada sisi objektif ia terstruktur secara sosial, karena atribut properti pada agen atau institusi yang mewakili dirinya sendiri dalam kombinasi yang memiliki kemungkinankemungkinan yang tidak sama. Pada sisi subjektifterstruktur, karena skema persepsi dan apresiasi, mengekspresikan status hubungan kekuatan simbol. Contoh: berat - ringan, tajam - tumpul, dan sebagainya. Bersama-sama dua mekanisme ini berfungsi untuk menghasilkan dunia yang umum, sebuah dunia berdasarkan akal sehat, atau setidaknya sebuah konsensus minimal dari dunia sosial. Jadi ruang sosial, direpresentasikan dalam bentuk agen yang di bantu dengan properti berbeda yang terhubung secara sistematis di antara mereka. Simbol memiliki kekuatan dalam "membentuk dunia"

Simbol mempunyai arti yang sangat penting dalam kehidupan manusia. Dalam setiap bidang hidup manusia, ungkapan simbolis merupakan jalan menuju kebebasan yang berdaya cipta. Fungsi simbol ialah merangsang daya imajinasi, dengan menggunakan sugesti, asosiasi dan relasi. Simbol merupakan alat yang kuat untuk memperluas penglihatan kita, merangsang daya imajinasi kita, dan memperdalam pemahamankitatentangdunia.BagiDillistone (2002), simbol sangat erat hubungannya dengan manusia. Pembahasannya tentang "The Power of Symbols" didasari oleh konsep Errnst Cassirer, bahwa manusia adalah animal symbolicum. Hanya dengan menggunakan simbol-simbol, manusia dapat mencapai potensi dan tujuan hidupnya yang tertinggi. Simbol yang paling kuat adalah manusia yang hidup. Manusialah yang menjadi simbol paling kuat dan paling patut dikenangkan, kadang-kadang oleh karena perkataannya, kadang-kadang oleh karena perbuatannya.

Walker (2004) melakukan studi tentang gagasan Melayu Pascakolonial, tentang kekuasaan - tentang hubungan antar masyarakat dan mereka yang mencari otoritas di atas mereka - dan tentang sumber- sumber aksi sosial dan identitas pada politik kebudayaan Melayu Pascakolonial. Penelitian ini sebagai sebuah sumber penting untuk informasi di antara isu-isu ini, sejarah Melayu (Raffles MS 18) mengidentifikasi kejadian-kejadian yang signifikan pada teks-teks penolakan dan masalah pluralisme dalam budaya politik Melayu. Analisis tersebut dibahas dalam Autonomy Diversity, and Dissent: Conceptions of Power and Sources of Action in the Sejarah Melayu (Raffles MS, 18).

Dari sejumlah hasil penelitian di atas, fokus kajian mengenai kekuasaan dikaitkan pada relasi antara posisi yang dominan dan marjinal.Sementara dalam kaitannya dengan simbol, mengartikan kekuatan simbol mampu memberikan pemahaman tentang dunia.Secara khusus kajian tentang bagaimana relasi kuasa bekerja dalam sukur bumi belum dibahas.Sehingga menjadi penting untuk dikaji selanjutnya di dalam tulisan ini.

"Power" dalam arti kekuasaan, seperti yang dirumuskan oleh Rederick Martin (1990, 77), bahwa kekuasaan adalah jenis arus informasi yang menampilkan tindakan yang tidak bersangkutan dengan masalah harga diri para penerima.Kekuasaan merupakan sifat suatu hubungan, bukan sifat-sifat individu. Kekuasaan merupakan suatu model komunikasi yang khas yang berbentuk tanda.Tetapi, kedua, tanda itu sendiri hanya berarti dalam acuan situasi tertentu para pelakunya, baik pengirim maupun penerima tanda-tanda atau arus informasi tersebut.

Kepatuhan, paksaan, otoritas, dan pengaruh merupakan istilah pokok yang kerap digunakan dalam kajian tentang kekuasaan. Lebih lanjut Martin (1990, 82), menjelaskan kepatuhan mengacu pada sikap dan prilaku yang disebabkan oleh kekuasaan.Tindakantindakan tersebut mengesampingkan dirinya sendiri karena sumpah (secara langsung atau tidak) kepada orang lain. Otoritas terletak di antara hak untuk berharap dengan ketaatan (pada) perintah. Karena itulah, Parsons mendefinisikan otoritas sebagai jenis keunggulan yang mencakup hak (dan/atau kewajiban) yang sah untuk mengendalikan 
tindakan-tindakan fihak lain di dalam sistem hubungan sosial. Sementara pengaruh adalah daya yang ada atau timbul dari sesuatu (orang, benda) yang ikut membentuk watak, kepercayaan, atau perbuatan seseorang.

Anderson (1990, 22) merumuskan kekuasaansebagai ...an abstraction deduced from observed patterns of social interaction; it is believed to derive from heterogeneous sources; it is in no way inherently self-limiting; and it is morally ambiguous. Hal penting dari urainnya adalah terdapat beragamnya sumber kekuaasan seperti: kekayaan, status sosial, jabatan formal, organisasi, senjata, populasi, dan sebagainya. Jika Anderson, menawarkan konsep sumber keuasaan, maka bagi Foucault yang terpenting adalah di mana kekuasaan tersebut beroperasi, seperti pernyataan berikut.

In feudal societies, powerfunctioned essentially through signs and levies. Signs of loyalty tothe feudal lords, rituals, ceremonies, and so forth, and levies inthe form of taxes, pillage, hunting, war, and so on. In the seventeenthand eighteenth centuries, a form of power comes into beingthat begins to exercise itself through social production andsocial service. It becomes a matter of obtaining productive servicefrom individuals in their concrete lives. (James D. Foubion, ed. 2001:125)

Tanda menjadi media dimana kekuasaan berfungsi, salah satunya pada sebuah ritual atau upacara.Tanda-tanda tersebut menjadi bagian dari kehidupan konkrit. Bagi Bourdieu tanda yang dimaksudkan di atas adalah media atau tempat. Kekuasaan sendiri diartikan sebagai kuasa simbolik, yakni berjalannya sebuah kekuasaan tidak nampak, bahkan berada di luar kesadaran, seperti dalam pernyataannya: .... symbolic power is that invisible power whichcan be exercised only with the complicity of those who do not wantto know that they are subject to it or even that they themselves (Bourdieu, 1991: 164)

Jika upacara sebagai arena beroperasinya kekuasaan, maka upacara bersifat politis, karena ia mengekspresikan relasi sosial kekuasaan dengan cara menaturalisasi tatanan sosial sebagai suatu 'fakta' niscaya, sehingga mengaburkan relasi eksploitasi di dalamnya. Artinya upacara sebagai tempat mengartikulasikan kekuasaan. Melalui upacara relasi kuasa tidak nampak (tak disadari), yang disebut simbolic power.

Kekuasaan simbolik yang dibahasakan oleh Antonio Gramsci sebagai hegemoni. Jika dalam kuasa simbolik bicara soal ketidaksadaran, maka dalam hegemoni sama artinya dengan menikmati. Kekuasaan menjalankan otoritas sosial dan kepemimpinanya atas kelas-kelas subordinat melalui kombinasi antara kekuatan dengan persetujuan (Chris Barker, 2008: 62). Bagi Gramsci, kekuasaan dapat dilanggengkan melalui strategi hegemoni. Hegemoni yang dimaksudkan oleh Gramsci ialah peran kepemimpinan intelektual dan moral (intellectual and moral leadership) untuk menciptakan ide-ide dominan. Kekuasaan diperoleh lewat hegemoni ide-ide (dalam wilayah budaya) yang didasarkan atas mekanisme konsensus.

Dari beberapa referensi konsep dasar tentang "power", ditemukan beberapa persoalan pokok, di antaranya: (1) Kekuasaan merupakan sebuah relasi (hubungan) yang bekerja dalam sebuah interaksi sosial; (2) Kekuasaan menciptakan dunia dan kebenaran; (4) Dalam kuasa simbolik, kekuasaan beroperasi dalam sistem tanda atau simbol; (5) Kekuasaan adalah hegemoni, dimana pihak yang dikuasai menikmati beroperasinya sebuah kekuasaan. Selanjutnya, persoalan pokok tentang "power" tersebut, secara metodis akan digunakan sebagai pisau untuk menganalisis reproduksi dan rekonstruksi sukur bumi. Dalam arti untuk menjawab pertanyaan, bagaimana relasi kuasa berkerja dalam upacara?

\section{PEMBAHASAN}

Rancakalong merupakan sebuah kecamatan yang berada di Kabupaten Sumedang, Propinsi Jawa Barat. Wilayahnyaberada tidak jauh dari lingkunan perkotaan (Bandung), dapat dijangkau dengan fasilitas transportasi yang cukup 
memadai. Rancakalong memiliki keadaan alam yang cukup khas. Keadaan alamnya dapat dikatakan masih asli. Terdapat gunung-gunung, bukit-bukit, hutan-hutan yang lebat mengitari bentangan sawah yang luas di antara rumah-rumah penduduk. Alam yang masih asli jauh dari keramaian dan polusi. Masyarakatnya menggantungkan hidup pada alam ini.Alam dijadikan sebagai sumber kehidupan.Alam tidak hanya dimanfaatkan oleh manusia dalam waktu sesaat, tetapi masyarakat mengolahnya dengan tetap menjaga keasliannya. Masih terdapat jejak pikiran mitis, bahwa alam merupakan bagian dari kehidupan manusia, menghancurkan ekosistem alam sama artinya menghancurkan kehidupan manusia. Kepercayaan terhadap kekuatan alam mewarnai cara hidup dalam keseharian masyarakatnya, seperti masih kuatnya penyelenggaraan upacara yang berkaitan dengan bentuk ucap sukur atas berkah alam. Upacara termasuk salah satu ruang ekspresi diri dan keyakinan masyarakat Rancakalong yang mayoritas pekerjaannya sebagai petani.

Upacara sakral mewarnai aktivitas masyarakatnya sepanjang tahun.Beragam upacara dilaksankan, ada yang setiap tahun sekali, setiap bulan sekali, juga ada yang dilaksakan setiap hari, atau upacara dilaksankan untuk waktu atau peristiwa penting/khusus, seperti kaul. Hal ini menunjukkan terdapat beragamnya jenis upacara. Upacara-upacar tersebut diantaranya: nyawen, hajat golong, nitipkeun dan nyalin, rayagungan, muludan, ngabubur, dan ngalaksa. Upacara-upacara inilah yang selanjutnya dalam tulisan ini disebut Sukur Bumi.

Secara spesifik Sukur Bumi yang menjadi fokus kajian adalah upacara ngabubur dan ngalaksa yang masingmasing dalam penyelenggaraannya selalu menyertakan tarawangsa.Tarawangsa sendiri merupakan alat musik dan musik, juga merupakan upacara, karena di dalam pelaksanaan pertunjukannya memiliki tata cara dan aturan termasuk perlengkapan sesaji secara khusus. Upacara ngabubur atau bubur suro adalah ritual membuat makanan dari berbagai macam bahan makanan yang dihasilkan dari bumi.Makanan, sayuran, dan buah-buahanan sebagai hasil dari pertanian dan perkebunan masyarakatnya.Makanan ini disebut juga sebagai makanan seribu rasa, karena dibuat dari kurang lebih seribu macam bahan makanan.Untuk menggenapkan jumlah seribu tersebut ditambahkan dengan cau sewu (pisang seribu).Ngalaksa merupakan ritual membuat makanan yang disebut laksa. Makanan dibuat dari beras melalui proses yang panjang, sekitar satu minggu.

Masyarakat Rancakalong melakukan reproduksi Sukur Bumi berdasarkan warisan dari leluhurnya. Tata cara dan aturan beserta simbol-simbolnya diwariskan secara turun temurun. Dalam perkembangannya kini, Sukur Bumi direkonstruksi oleh pemerintah bersama masyarakat.Salah satu model rekonstruksi tersebut dilakukan pada upacara ngalaksa.Kajian tentang relasi kuasa dilakukan pada reproduksi dan rekonstruksi Sukur Bumi tersebut.Bentuk relasi kuasa dianalisis melalui wacana yang menyebar di dalam praktik Sukur Bumi. Data-data ditemukan melalui wawancara dari beberapa sumber, yang masing-masing memiliki peran penting dalam kaitannya dengan upacara, seperti: pupuhu dan saehu, yang berperan sebagai pemimpin upacara; canoli, sebagai pemilik rurukan (tempat upacara) yang memiliki garis keturunan langsung dari penyelenggara upacara sebelumnya; pemain tarawangsa dan jentreng, yakni seniman yang menguasai atau mumpuni dalam memainkan musik tarawangsa; dan salah satu pejabat pemerintah.Selain berdasarkan data hasil wawancara, kajian yang lebih bersifat kualitatif ini juga berdasarkan pengamatan yang dilakukan mulai tahun 2007 hingga sekarang.Untuk selanjutnya relasi kuasa dalam Sukur Bumi tersebut, diuraikan sebagai berikut.

\section{Antara Otoritas dan Hegemoni}

Kekuasaan sebagai otoritas memberikan implikasi adanya struktur hirarki. Pemilik jabatan-jabatan tertentu sebagai penguasa. 
Kekuasaan berdasarkan otoritas yang dimiliki tersebut, secara bersamaan bagi penerima kekuasaan tersebut diterima sebagai hegemoni.Hal ini seperti relasi antara pemerintah dan masyarakat.Otoritas kekuasaan sudah nampak, menunjukkan pemerintah berada dalam posisi penguasa dan masyarakat yang dikuasai.Hirarki struktural inilah yang mempertegas garis antara hak dan kewajibannya.Namun persoalan terpentingnya, adalah bagaimana bentuk kekuasaan tersebut berjalan, dalam model hubungan komunikasi yang berada dalam Sukur Bumi.Dalam konteks reproduksi Sukur Bumi, relasi kuasa antara masyarakat dan simbol-simbol upacara. Masyarakat memposisikan upacara sebagai objek pemaknaan yang bebas dan adaptif. Sementara dalam rekonstruksi Sukur Bumi, relasi kuasa dapat dilihat dari cara pandang pemerintah dalam memposisikan Sukur Bumi sebagai aset budaya. Lebih lanjut bentuk kekuasaan tersebut, dapat dilihat sebagai berikut.

\section{Struktur Jabatan}

Dalam konteks rekonstruksiSukur Bumi, struktur jabatan dalam pemerintahan seperti bupati, camat, kades, dan semua perangkat atau staf-stafnya, diposisikan sebagai pemilik otoritas kekuasaan.Pemerintah memiliki otoritas penuh dalam menentukan kebijakan terhadap rekonstruksi Sukur Bumi.Masyarakat atau para pelaku upacara dengan sendirinya memiliki kewajiban untuk patuh.Kepatuhan ini pun dikuatkan oleh salah satu prinsip hidup yang dimiliki oleh masyarakatnya, yakni: "ngabakti ka nagara", yang memberikan arti, bahwa sebagai anggota masyarakat yang baik berkewajiban mematuhi dan mengikuti aturan-aturan yang telah ditentukan oleh pemerintah.

Relasi antara pemerintah dan masyarakat, dapat diartikan antara penguasa dan rakyat.Masing-masing sebutan memiliki atribut karakteristiknya, seperti pemerintah sebagai pihak yang paling besar/pembesar, berada di atas/paling tinggi. Sudah jelas ia merupakan pengemban keuasaan.
Sebaliknya, rakyat adalah pihak yang berada di bawah, kecil, tidak punya kendali, adalah dia sebagai sasaran kekuasaan. Namun demikian, dalam pernyataan diatas kekuasaan dikonstruksi sebagai sebuah hegemoni.Masyarakat dibuat menikmati posisinya.

\section{Pupuhu dan Saehu}

Struktur jabatan juga ditemukan dalam level hubungan di dalam masyarakat itu sendiri, yakni dalam praktik reproduksi Sukur Bumi. Dalam reproduksinya, Sukur Bumi yang ada di Rancakalong dilaksanakan berdasarkan rurukan ${ }^{1}$ masing-masing. Setiap rurukan memiliki pupuhu dan saehu. Pupuhu, adalah orang yang dituakan ${ }^{2}$ di rurukan (kelompok), memiliki kemampuan lebih dari anggota masyarakat lainnya. Sama halnya dengan sebutan saman. Selain, memiliki garis keturunan terdekat dengan karuhun, ia juga memiliki kemampuan "berdoa", yang mampu menjadi perantara komunikasi dengan leluhur (keturuan yang telah meninggal). Pupuhu adalah orang yang paling tahu bagaimana seharusnya upacara dijalankan, ia memiliki kemampuan untuk menjadi tempat bertanya atau pertimbangan berbagai hal yang berkaitan dengan upacara. Sementara, saehu adalah orangyang dipercaya memimpin jalannya upacara, terutama pada pertunjukan tarawangsa.Saehu-lah yang mengawali ibingan, baik untuk ibingan istri maupun ibingan pameget.Oleh karenanya, saehu ada dua, saehu pameget dan saehuistri.

Posisi ini sangat mempengaruhi dalam pengelolaan $^{3}$ upacara.Meskipun struktur tugas tersebut tidak nampak secara langsung, namun sebutan pupuhu dan saehu nampak berada dalam posisi sebagai pemimpin. Merekalah yang mengatur jalannya upacara. Mulai dari pengaturan waktu, tempat,

\footnotetext{
1 Rurukan adalah kelompok adat.Sebutan untuk kelompok masyarakat yang melaksankan upacara berdasarkan garis keturunan masing-masing. Nama rurukan disesuaikan dengan nama dusun atau kampung tempat tinggal kelompok adat.

2 Tua, bukan berdasarkan umur, tetapi berdasarkan kemampuan yang dimilikinya.

3 Dalam cara yang tradisional, masyarakat (pelaku upacara) memiliki pengelolaan atau pengaturan sendiri dalam melaksanakan upacara.
} 
materi, dan seluruh perangkat dan syarat upacara dilaksanakan berdasar kebijakan dari pupuhu dan saehu.Semua anggota patuh.

\section{Pemilik Modal}

Kekuasaan simbolik, bagi Bourdieu, dalam mengoptimalkan kekuatannya sangat tergantung pada dua hal (Bourdieu, 1990:137138). Pertama, seperti halnya wacana performatif, kekuasaan simbolik didasarkan pada kepemilikan modal simbolik (simbolik capital). Semakin besar seseorang atau suatu kelompok memiliki modal simbolik, semakin besar peluangnya untuk menang. Artinya, modal simbolik merupakan kredit bagi terbentuknya otoritas sosial yang diperoleh dari pertarungan sebelumnya.Lebih lanjut, konsep kuasa simbolik Bourdieu (1986: 243), terdapat jenis modal ekonomi, yakni modal yang dikonversikan langsung dalam bentuk uang.

Dalam konteks rekonstruksi upacara ngalaksa, pemerintah memposisikan diri sebagai pemilik tunggal modal ekonomi. Untuk penyelenggaraan upacara ngalaksa, pemerintah bantuandana dan fasilitas (tempat penyelenggaraan upacara). Dengan modal itulah, pemerintah memiliki kuasa dalam merekonstruksi Sukur Bumi berdasarkan kepentingannya.Kini, ngalaksa tidak saja dilaksanakan seperti cara-cara yang dilakukan oleh masyarakat, sebagai pewaris kebudayaan, tetapi telah memiliki warna baru sesuai dengan cara pandang pemerintah. Model rekonstruksi tersebut di antaranya: penyelenggaraan dilaksanakan di tempat khusus yakni di Desa Wisata; adanya seremoni pembukaan acara; memiliki penyelenggara atau kepanitiaan khusus; diselenggarakannya pasar malam; membedakan antara pelaku dan penonton; dan tarawangsa menjadi pertunjukan tontonan. Sebagai pemilik modal, pemerintah memiliki kuasa dalam merumuskan kembali model upacara sesuai dengan selera pasar (pariwisata).Meskipun pada bagian luar, rekonstruksi Sukur Bumi telah mengalami proses perubahan dari bentuk reproduksinya.

\section{Legalitas formal}

Menurut cerita masyarakat, konon Sukur Bumi dilaksanakan di rurukan masing-masing secara tersembunyi, agar tidak diketahui secara luas, terutama oleh pemerintah. Seperti yang dijelaskan oleh Karmita:
janten kapungkur mah ngalaksanakeun ngalaksa teh dinu suni-suni sanes di lembur kieu ngalaksanakeun boh ngalaksa boh ngabubur. Milari tempat anu kira-kira tiis, teu kacorogok ku jalmi, ....Naon margina, waktos harita jaman DI curiga, pamarentah sieun aya politik, gorombolan, dina ririungan. Urang sieun $k u$ pamarentah, ... ieu teh musuh atanapi sanes. ....Ayeuna pamarentah ngalestarikeun, ...nya alhamdulillah dipangdamelkeun, nya dipasihan tanahna, sawahna, saungna, nya ka balong-balongna. (Wawancara, tanggal 3 Oktober 2010).(Jadi pada jaman dulu, melaksanakan ngalaksa di tempat sepi, bukan di perkampungan, baik melaksanakan ngalaksa mapupun ngabubur. Mencari tempat yang sekiranya dingin, sulit dijangkau oleh orang, ....Kenapa, pada waktu itu di jaman DI curiga, pemerintah takut, ada politik, gerombolan, dalam perkumpulan tersebut. Kita takut oleh pemerintah, ...ini musuh atau bukan. ... Sekarang pemerintah melestarikan... ya alhamdullah dibuatkan, diberi tanahnya, sawahnya, tempatnya, dan kolamnya).

Hal senada juga disampaikan oleh Pupung (Wawancara, tanggal 3 Oktober 2010), sebagai berikut: pan kapungkur seni budaya talari paranti dicaram $k u$ ajaran $k a$ Islaman teh (dulu seni budaya dan adat istiadat dilarang oleh ajaran agama Islam). Larangan terhadap aktivitas upacara, berkaitan dengan dominasi Agama Islam yang berkembang di wilayah itu.Dalam pandangan Islam, cara-cara upacara disinyalir sebagai bentuk agama, selain agama Islam.

Menghadapi situasi seperti ini, masyarakat merasa perlu mendapat perlindungan dari pihak pemerintah, bahwa apa yang mereka lakukan adalah semata kepentingan kebudayaan. Legalitas formal yang diberikan oleh pemerintah terhadap penyelenggaraan upacara memberikan rasa aman bagi masyarakat.Inilah bentuk hegemoni.Merekatidaklagimerasaketakutan 
upacara yang telah menjadi reproduksinya dianggap tidak legal atau musyrik ${ }^{4}$. Legal formal yang diberikan pemerintah memberikan ketenangan dan kebebasan bagi masyarakat dalam mengekspresikan dirinya dalam Sukur Bumi.

Legalitas formal ini juga dipertegas oleh pernyataan Karyono, Camat Rancakalong (wawancara, 23 Nopember 2011): pemerintah hanya melegalisasi saja, jangan sampai punah, kalo ini tidak dilegalisasi, masyarakat ketakutan, dibilang musrik.Relasi kuasa bekerja dalam konteks ini (legalitas formal). Mengatasnamakan kebutuhan masyarakat, pemerintah memberikan legalitas formal atau semacam ijin atau kelegalan dari upacara yang biasa dilaksankan. Pemerintah memenuhi kewajibannya melindungi masyarakat.Kepemilikan legalitas formal inilah, secara tidak langsung memberikan otoritas bagi pemerintah dalam merekonstruksi penyelengaraan upacara.

Dalam otoritas kekuasaan, pemerintah punya posisi lebih tinggi, sehingga ia punya hak untuk mendapatkan status atau posisi atau jabatan tertentu dalam bidang kebudayaan. Kepatuhan yang dilakukan oleh masyarakat berdasarkan otoritas yang dimiliki oleh pihak pemerintah, yang memiliki kuasa dalam melakukan perintah sekaligus permintaan.Secara bersamaan masyarakat menjalankannya sebagai sebuah kewajiban, karenanya secara sadar masyarakat menikmati posisi tersebut.Dalam pandangan Gramcsi, model relasi kuasa ini disebut hegemoni, dimana masyarakat bukan saja tidak menyadari adanya relasi kuasa, bahkan menikmatinya.

Bagi Gramsci, hegemoni merupakan situasi dimana kelas berkuasa menjalankan otoritas sosial dan kepemimpinan atas kelas-kelas subordinat melalui kombinasi antara kekuatan dengan persetujuan (Chris Barker, 2000:62). Bagi Gramsci, kekuasaan dapat dilanggengkan melalui strategi hegemoni. Rekonstruksi Sukur Bumi merupakan bentuk hegemoni kekuasaan. Sukur Bumi merupakan arena dimana relasi kuasa berlangsung.Melalui hegemoni, ide-ide yang diciptakan penguasa untuk menentukan struktur kognitif masyarakat. Upaya hegemoni ini berlangsung sebagai cara menggiring persepsi orang dalam kerangka yang telah ditentukan oleh negara.Rekonstruksi lahir sebagai ide baru untuk menguntungkan pemerintah, dan masyarakat menikmati keuntungan tersebut, karena secara bersamaan mereka mampu memenuhi kebutuhan kulturalnya.

\section{Kuasa Simbolik Mengkonstruksi Pengetahuan}

Jika upacara sebagai arena beroperasinya kekuasaan, maka upacara bersifat politis, karena ia mengekspresikan relasi sosial kekuasaan dengan cara menaturalisasi tatanan sosial sebagai realitas, sehingga mengaburkan relasi eksploitasi di dalamnya. Artinya upacara sebagai alat mengartikulasikan kekuasaan. Melalui upacara relasi kuasa tidak nampak (tak disadari), yang disebut simbolic power. Seperti yang jelaskan Pierre Bourdieu (1991: 164)

.... symbolic power is that invisible power whichcan be exercised only with the complicity of those who do not wantto know that they are subject to it or even that they themselves.

Sukur Bumi merupakan simbol, yang di dalamnya terdiri dari upacara-upacara, sementara upacara pun simbol yang di dalamnya memiliki ritus-ritus.Artinya, Sukur Bumi memiliki lapisan simbol. Lapisan tersebut menunjukkan, bahwa Sukur Bumi terdiri dari beragam upacara, di dalam pelaksanaannya terdapat ritusritus yang masing-masing memiliki unsurunsur, seperti sesaji, peralatan upacara, seni pertunjukan, dan lain-lain.Lebih jelasnya dapat digambarkan dalam bagan berikut.

4 Musyrik, adalah istilah dalam agama Islam, yang artinya menyekutukan Allah. Ada anggapan musyrik terhadap penyelenggaraan sukur bumi, karena tata caranya dianggap melakukan penyembahan terhadap benda-benda lain, dalam arti melakukan penyembahan kepada selain Allah. 


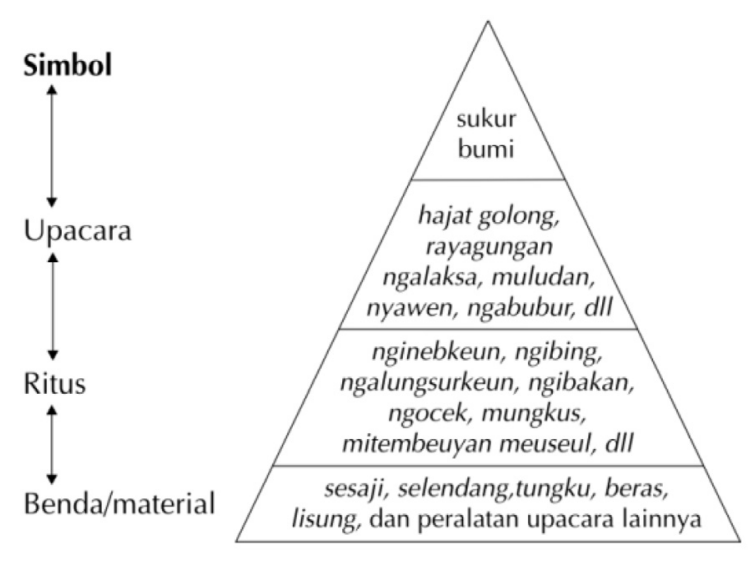

Tabel 1

Lapisan simbol dalam Sukur Bumi

(Desain: Yanti Heriyawati, Desember 2011)

Sebagai simbol, Sukur Bumi memiliki makna. Dalam konteks reproduksi, Sukur Bumi tentu mengalami proses pemaknaan yang berkembang, seiring dengan proses pergantian masyarakat penyangganya. Sukur Bumi dibaca kembali dengan cara berfikir masyarakat kini, sebagai pelaksananya, meskipun mereka menganggap sebagai pewaris, namun belum tentu warisan tersebut mampu diterima secara utuh dengan konstruksi pikirannya. Nyatanya, makna tersebut sebagian telah tercampur dengan cara berpikir masyarakat kini. Inilah salah satu konsekuensi dari sebuah reproduksi, seperti yang dinyatakan oleh Irwan Abdulah (2006, 41), Reproduksi artinya membuat pengelompokan baru, menentukan definisi baru, pemberian makna baru, sebagai kekuatan dalam mengubah berbagai ekspresi kultural. Proses reproduksi kultural merupakan proses aktif untuk mengharuskan adaptasi.

Adaptasi seperti apakah yang dilakukan oleh masyarakat Rancakalong, apakah pada simbol dan cara-cara pelaksanaanya?Atau pada maknanya?Jawabannya, tentu bisa dilakukan pada keduanya. Karena, tak ada yang bisa memastikan, bahwa seluruh unsur atau symbol-simbol yang digunakan dalam upacara sama persis seperti yang dilakukan oleh leluhurnya. Sangat mungkin ada beberapa yang diganti, dengan tidak mengurangi maksud atau maknanya.
Sebaliknya, justru dengan tanpa disadari makna telah mengalami perubahan seiring perubahan masyarakatnya.

Dalam kasus pertama, sebagai contoh: dalam pelaksanaan upacara Ngalaksa, ada ritus ngibakan nu Geulis (memandikan beras). Ritus ini biasanya dilaksanakan di mata air langsung, tapi untuk menuju mata air dibutuhkan waktu yang lama, sehingga yang dilakukan sebaliknya, bukan mendatangi mata air, tetapi airnya yang didatangkan langsung ke tempat, dengan menggunakan pipa (saluran air). Ini bukti cara berfikir manusia sekarang, lebih praktis dengan tidak mengubah makna arti ngibakan. Beras tetap di cuci dengan air dari mata air, dengan tidak meninggalkan tahap-tahapnya, termasuk kekhusuan dan kesakralan dalam melaksanakannya.Tak ketinggalan dengan iringan tarawangsa-nya. Inilah cara masyarakat sebagai pewaris, dalam mengkonstruksi pengetahuannya sendiri sebagai makna kebenaran.

Contoh untuk kasus kedua, seperti: Tarawangsa merupakan musik, alat musik, dan upacara sekaligus, yang selalu dikaitkan dengan Padi yang disebut Nyi Pohaci. Sebutan Nyi Pohaci berkaitan dengan cara berpikir masyarakat lama, terutama dalam masyarakat Sunda Lama. Namun demikian, salah satu makna dari Tarawangsa, terutama pada penggunaan senar, dikaitan dengan keIslam-an, seperti yang dijelaskan oleh salah seorang saehu:

Anu tujuh lembar kawat diterapkan dina kacapi. ..disangkutkana 2 lembar kawat tarawangsa. ...lamun disinkronkeun kana para wali, tujuh sareng dua berarti salapan. Ka para wali anu salapan ka sapuluh wali tunggal Allah SWT (Mulyadi, wawancara tanggal 9 Januari 2009). (Yang tujuh lembar kawat digunakan pada kacapi. ...dikaitkan dengan dua lembar kawat pada tarawangsa. ... jika dihubungkan kepada pawa wali, tujuh dan dua menjadi Sembilan. Ke para wali yang Sembilan, kesepuluh wali tunggal Allah SWT).

5 Ritus ngibakan di sini dalam Upacara Ngalaksa yang dilaksanakan di Desa Wisata. 
Masyarakat Rancakalong masih menggunakan tarawangsa sebagai simbolnya, tetapi dalam pemaknaanya diadaptasi dengan kondisi manusianya yang menganut agama Islam, meskipun tarawangsa telah ada sebelum Islam masuk.Inilah bentuk pilihan yang mampu meyakinkan seluruh anggota masyarakat agar dalam posisi tertentu mereka terlindungi.Sehingga secara sengaja dibuat pengetahuan sendiri yang kemudian dikontruksi sebagai kebenaran makna.

Sistem simbol memiliki kekuatan untuk memberikan pemaknaan bagi realitas sosial. Lewat proses pencitraan, sistem simbol memperoleh daya abstraknya guna mengubah makna, menggiring cara pandang, hingga mempengaruhi praktik seseorang maupun kelompok (Bourdieu, 1991: 170). Sukur Bumi merupakan suatu sistem simbol yang memiliki makna tersendiri bagi masyarakatnya.Sukur Bumi sebagai bagian tak terpisahkan dari kehidupan masyarakatnya.Ia menjadi bagian penting di antara aktivitas sehari-hari. Makna-makna tersebut dapat dilihat dari beberapa upacara atau ritus, sebagai berikut.

Pertama, kekuatan simbolik yang dimiliki oleh tarawangsa.Musiknya mampu membawa penarinya masuk ke dunia "antara". Ibingan nyurup ${ }^{6}$ menjadi impian dan harapan warga agar mampu menyatu dengan karuhun (leuhur), bertemu jiwa, bersapa hati. Hal ini bukan saja menjadi pengetahuan tetapi telah menjadi keyakinan.Musik dan ibingan tarawangsa menjadi jalan pencerah diri dan percaya diri, karena kondisi nyurup menjadikan penarinya nampak kasep dan geulis.

Hampir setiap aktivitas kehidupan masyarakat Rancakalong selalu disertai dengan Tarawangsa.Ia selalu hadir, tidak saja dalam aktivitas upacara yang rutin, tetapi Tarawangsa mampu menjadi media pengobatan dan permohonan. Seperti pernyataan berikut.

6 Menari dalam keadaan antara sadar dan tidak sadar. Hal ini berbeda dengan ibingan kasurupan dan susurupan.Bagi masyarakatnya, kasurupan berarti menari dalam keadaan tidak sadar, sementara susurupan adalah menari dengan pura-pura nyurup atau purapura tidak sadar.
Kadang-kadang seni tarawangsa ieu teh tiasa oge dianggo landong. Contona, upami hoyong ningkatkeun, dina perkawis jabatan, atanapi dina perkawis kaluluhan kitu. Insyaalloh dibantos $k u$ seni kahormatan ieu.(Tata, wawancara tanggal 8 Januari 2009)(Terkadang seni tarawangsa ini bisa digunakan untuk pengobatan, contohnya, jika ingin meningkatkan jabatan, atau posisi. Insyaallah dibantu dengan seni kehormatan ini)

Masyarakat memposisikan Pertunjukan Tarawangsa sebagai media pengobatan. Keyakinannya sebagai modal pengetahuan yangmampumemberikanefekpenyembuhan. Ia pun menjadi modal atau motivasi dalam mencapai berbagai cita-cita atau harapan dalam hidup. Inilah salah satu yang nyata, bahwa tarawangsa punya kekuatan mengatur kehidupan masyarakatnya.Ia sebagai kontrol kehidupan, hadir dan bermakna khusus dalam seluruh aktivitas masyarakatnya, dalam keadaan suka duka. Tarawangsa tidak saja untuk menangani persoalan hidup tetapi juga dalam kesenangan hidup, karenanya Tarawangsa juga sebagai media hiburan, sebagai ruang ekspresi diri.Tidak sedikit warga yang sengaja nanggaptarawangsa sebagai pakaulan atau nadar ${ }^{7}$ untuk mendapatkan berkah.

Berkah yang didapatkan tidak saja karena suka cita dalam ibingan, tetapi juga, karena melaui upacara tarawangsa setiap individu memiliki ruang untuk berserah diri, dengan jujur dan pasrah melakukan proses evaluasi diri. Dengan cara ini, setiap individu mampu melakukan ibingan yang nyurup, sehingga tujuan hidup akan tercapai. Karenanya, dalam upacara, setiap individu diuji diri, dibaca laku lampah (prilaku).

Kedua, sesaji sebagai petunjuk hidup. Salah satu kelengkapan upacara yang tidak boleh ditinggalkan adalah seperangkat sesaji. Ia merupakan simbol yang memiliki makna penting bagi kehidupan manusia. Seperti dijelaskan Pupung (wawancara, tanggal 3 Oktober 2010)' sebagai berikut.

\footnotetext{
$7 \quad$ Pakaulan atau nadar, merupakan bentuk bentuk ucap janji, yang diekspresikan dalam bentuk sukuran, dengan mengundang pertunjukan tarawangsa.
} 
...sasajen anu sakitu leuyana teh, sanes keur dewa, keur setan siluman atanapi karuhun.Tapi simbul siloka didina teh, aya guareun, kitab anu teu tertulis, tapi nu aya di alam.(...sesaji yang segitu banyak, bukan untuk dewa atau setan, atau karuhun.Tapi simbol untuk dibaca, kitab yang tidak tertulis, tapi aya di alam).

Material yang digunakan sebagai sesaji, merupakan satu bagian yang tidak terpisah, antara unsur satu dan yang lainnya memiliki makna yang saling berkaitan.Jika tidak ada satu unsur, maka tidak sempurnalah sebuah upacara atau ritus tersebut.Tujuan pun tidak akan tercapai. Salah satu makna dari sesaji adalah pada parupuyan $^{8}$, yakni bara api yang disimpan disebuah wadah, yang digunakan untuk membakar kemenyan, menghasilkan asap. Berdasarkan penjelasan Pupung (2010) parupuyan mengandung makna:

Ari kukus nyaeta surat dimana urang aya kereteg manah, dinu sur sampiur, bisa ngotret dinu kertas, atanami dinu sangu putih menyan tea, ujungna kanu maha kawasa. Oge seungit, terus ngebulna bodas. Urang teh nyekar, ngadoa teh dinu jalan hade, bersih, sanaos aya ruhakna dina seungitna. (kukus atau parupuyan adalah surat, apa yang kita rasakan dalam hati yang paling dalam, bisa dituliskan dalam keras atau nasi putih yaitu kemenyan, ujungnya ke yang Maha Kuasa. Wanginya terus mengepul putih. Kita berdoa di jalan yang benar, bersih, walaupun ada bara di antara wanginya).

Manusia tidak lepas dari salah.Kebaikan berada di antara keburukan.Benar salah, baik buruk, saling berpasangan yang selalu ditemukan dalam kehidupan. Oposisi ini adalah ujian, sejauh mana manusia mampu mencapai berkah hidup atau apa yang disebut harmoni.

Ketiga, makna ngabubur.Ngabubur, bukan saja soal bagaimana cara membuat makanan yang disebut bubur sarebu, tetapi juga memiliki seribu makna (baca: banyak makna). Makna tersebut tentu berkaitan

8 Parupuyan, hanya salah satu kelengkapan sesaji, di antara sejumlah sesaji yang harus disediakan dalam pelaksanaan upacara atau pertunjukan tarawangsa. dengan cara hidup. Ngabubur mengandung petuah/ajaran, bagaimana cara kita hidup sebagai makhluk sosial, seperti dijelaskan Ma Ukus (wawancara, tahun 2008), sebagai berikut.

...jadi bubur wae.Kajeun anu haseum, anu pait, anu peuheur, breg ka dinya, cobi engke raosan buburna ...moal asa kalapa wungkul, moal asa sampeu wungkul, moal asa gedang wungkul.Estuning ngahiji eta. Tah, ...sareatna, manusa teh kudu kieu. ...bisi anu beurat sok tulungan; bisi sok cilaka sok bantuan, kitu. Nu disebat nulung ka nu butuh nalang ka nu susah, mere ka pakir miskin. Ka tamu geuwat aku, mun aya geuwat suguhan.Tah eta anu jadi paling utamina mah.

(Jadi bubur saja. Biar yang asem, pahit, hambar, semua disatukan, nanti buburnya ...tidak akan terasa kalapa saja, singkong saja, papaya saja. Semuanya menyatu. Ini materialnya..manusia harus gini. ... kalo yang berat di tolongin, yang celaka di bantuin. Yang disebut menolong ke yang butuh, membantu ke yang susah, nagsih ke pakir miskin. Ke tamu cepat diterima dengan baik, kalo ada cepat diberi makanan. Inilah hal yang paling utama).

Di Rancakalong, upacara ngabubur dilaksanakan di beberapa rurukan. Masingmasing memiliki tata cara dan aturan yang hampirsama. Pemaknaanyangberbedasecara subjektif merupakan bukti keberagaman. Artinya simbol yang sama dapat dimaknai beragam. Masing-masing pengalaman yang mengikat pemaknaan subjektif, atas apa yang diyakini dari ngabubur seperti yang diceritakan oleh Karmita (wawancara, tanggal 3 Oktober 2010), sebagai berikut.

Bubur teh nyaetan: hiji ngalebur, kaduana sukuran urang $k u$ ayana di hirupkeun, dihuripkeun. Dihirupkeun dipasihan $k u \quad n u$ Maha Kawasa, ayena ngahuripkeun ku ayana katuangan. Ngaleburna, ngalebur dosa, katiluna nyuburkeun, naon bae anu dicecebkeun ku urang, boh bubuahan beubeutian, sing aya barokahna, jeung mangfaatna.(bubur adalah: pertama melebur, kedua kita bersyukur karena diberi kehidupan. Kehidupan yang diberi dari Maha Kuasa, sekarang dihidupkan karena ada makanan. Meleburkan dosa, ketiga 
menyuburkan, apa saja yang tanam oleh kita, buah-buahan, umbi-umbian, agar ada berkkah dan manfaatnya).

Dalam makna yang berbeda secara subjektif, ngabubur tetap memiliki garis nilai yang sama, sebagai bentuk ucap sukur sekaligus cara bagaimana menjalani hidup sebaik-baiknya. Ngabubur, memberikan pengetahuan bagi masyarakatnya dalam menjalani realitas.Jika upacara merupakan tempat bekerjanya jaringan kuasa, maka kuasa itu mengkonstruksi pengetahuan tentang realitas dan dunia makna. Hal ini seperti yang dikatakan Bourdieu (1991: 166), bahwa Symbolic power is a power of constructing reality.

Simbol dalam Sukur Bumi telah menunjukkan kuasanya dalam merepresentasikan realitas.Realitas sendiri dipresentasikan lewat logika simbol. Simbol memiliki kekuatan dalam cara pandang manusia terhadap dunia dan, karenanya, cara bertindak terhadap dunia, dan dengan demikian mengubah dunia itu sendiri. Seperti yang dijelaskan Bourdieu $(1991,170)$.

.....What creates the power of words and slogans, apower capable of maintaining or subverting the socialorder.is thebelief in the legitimacy of words and of those who utter them. Andwords alone cannot create this belief.

Kekuatan simbol juga di dukung oleh adanya legitimisi dan sistem keyakinan, yang karenanya ia punya kuasa mengubah cara pandang manusia terhadap dunia. Sistem keyakinan dan legitimasi kekuasaan memiliki kekuatan dalam mempertahankan sekaligus menghancurkan tatanan sosial.

Model kuasa simbolik juga dapat dilihat pada rekonstruksi upacara ngalaksa. Dalam kuasa simboliknya Bourdieu, selain modal ekonomi, terdapat modal budaya dan modal sosial. Modal dalam kuasa simbolik akan menentukan posisinya dalam kekuasaan yang dimilikinya. Modal budaya dan modal sosial salah satu yang berupaya dikonstruksi sendiri oleh pihak pemerintah. Seperti: berdasarkan penjelasan dari Pejabat (Karyono, wawancarar tanggal 23 Nopember
2011) setempat, terdapat sebutan "Pemangku Adat" bagi Camat, dan "Pemangku Budaya" bagi Bupati. Istilah pemangku, merupakan istilah Bahasa Sunda, yang artinya pemegang, dalam arti lain lebih menjelaskan sebagai pimpinan. Istilah "adat" dan "budaya" merupakan posisi dan persoalan yang paling penting dalam kebudayaan.Istilah "pemangku" jelas telah memposisikan pemerintah sebagai pimpinan tertinggi, punya kuasa penuh dalam memberikan kebijakan apapun terhadap Sukur Bumi.

Kuasa simbolik nampak pula pada bagaimana pemerintah membangun sebuah tempat upacara ngalaksa yang disebut "Desa Wisata", yang sengaja disiapkan untuk mengkonstruksi pikiran masyarakat, bahwa tarawangsa sebagai aset budaya. Wacana pariwisata, cukup kuat sebagai bentuk kekuasaan simbolik.Konteks ini senada dengan pendapat Bourdieu (1991: 167), bahwa beredarnya kekuasaan dalam sebuah hubungan komunikasi, sangat ditentukan oleh materi yang disiapkan oleh agen.Penataan hubungan seolah terstruktur, sehingga dominasi tidak nampak bagi kelas penerima.Sebagai bentuk hegemoni, masyarakat menerima bentuk rekonstruksi. Sehingga kebenaran yang ditemukan, bahwa pemerintah peduli dengan memberikan fasilitas tempat.Tidak lagi nampak, bentuk legitimisasi kekuasannya.

"Seremoni" sebagai materi dari model rekonstruksi ngalaksa.Ia menjadi media show kekuasaan, sehingga masyarakat makin meyakini posisi tertingginya pihak pemerintah. Hal ini, dipertegas oleh Bourdieu:

...the power to impose(or even to inculcate) the arbitrary instruments of knowledge andexpression (taxonomies) of social reality - but instruments whosearbitrary nature is not realized as such. (Bourdieu 1991: 168).

Model rekonstruksi upacar ngalaksa merupakan tempat dalam mengkonstuksi pengetahuan. Sesungguhnya ia berisi instrumen-instrumen pengetahuan baru yang mengutamakan keuntungan 
pemerintah. Pengetahuan tersebut dianggap paling benar, sehingga semua pihak sepakat dan menerima, karena kebenaran tersebut menunjukkan rasionalitasnya.

...Truth... is produced only by virtue of multiple forms of constraint. And it induces regular effects of power. Each society has itsregime of truth, its "general politics" of truth-that is, the types ofdiscourse it accepts and makes function as true; the mechanismsand instances that enable one to distinguish true and false statements; the means by which each is sanctioned; the techniques andprocedures accorded value in the acquisition of truth; the status ofthose who are charged with saying what counts as true. (Foucault, 1980:131)

Bagaimana upaya pemerintah dalam memposisikan dirinya dalam mengkonstruksi Sukur Bumi adalah jalan untuk memperebutkan kekuasaan dalam praktik kebudayaan. Melakukan rekonstruksi terhadap Sukur Bumi yang diperkuat dengan rumusan-rumusan konsep tentang kebudayaan, sebagai cara menunjukkan diri, bahwa pemerintah memiliki pengetahuan yang lebih banyak tentang kebudayaan. Hal ini dijadikan sebagai modal budaya sekaligus modal sosial. Dengan demikian, upacara sebagai ruang bagi pemerintah dalam mewacanakan ideologinya. Seperti wacana pariwisata dan ekonomi rakyat. Upacara dijadikan media untuk mengartikulasikan kekuasaan. Ia merupakan produk relasirelasi kekuasaan dan pada saat yang sama memproduksi kebenaran.Kekuasaan tidak lagi dalam bentuk fisik melainkan bekerja dalam arena representasi, dirumuskan dalam simbol. Kekuatan upacara untuk menciptakan realitas tidak berasal dari dirinya melainkan secara simbolik yang menjadi fokus konsentrasi di dalamnya.Simbol sebagai kekuatan yang abstrak memiliki sumber daya yang ampuh dalam mencipta kebenaran.

\section{Upacara sebagai kekuatan Budaya}

Jika ada hal yang dapat disetujui oleh para penulis cultural studies, maka hal itu adalah arti penting konsep kekuasaan, yang dipandang terdapat pada setiap level hubungan sosial. Kekuasaan bukan hanya sekedar perekat yang menyatukan kehidupan sosial, atau kekuatan koersif yang menempatkan sekelompok orang di bawah orang lain, meskipun pada dasarnya memang demikian. Kekuasaan juga merupakan proses yang membangun dan membuka jalan bagi adanya segala bentuk tindakan, hubungan atau tatanan sosial. Dalam hal ini, kekuasaan, meskipun benar-benar menghambat, juga melapangkan jalan (Chris Barker, 2000:11).

Upacara mempunyai kekuatan menghadirkan banyak orang berkumpul dengan niat dan cara ekspresinya masingmasing. Dalam konteks reproduksi, upacara menjadi ruang interaksi sosial, menyatukan masyarakat dalam sebuah tatanan kehidupan sosial. Setiap individu saling menyadari adanya relasi kuasa, yang diwujudkan dalam cara kerja. Masing-masing menjalankan tugas bukan berdasarkan otoritas semata.Setiap individu patuh, karena kesadaran atas kuasa yang dimiliki masing-masing individu.

Sadar ataupun tidak, upacara telah menciptakan sebuah tatanan sosial.Upacara bermuatan pengetahuan dan kebenaran yang diyakini semua pihak untuk menjalankan berbagai kepentingannya.Upacara menjadi penuntun dalam mengkonstruksi sistem kehidupan.Ia menjadi media dalam melihat masa lalu dan masa depan, sekaligus proses adaptasi terhadap berbagai perubahannya. Masyarakat Rancakalong melakukan reproduksi sukur bumi, bukan saja soal kewajiban yang diwariskan secara turun temurun, tetapi juga secara tidak langsung merupakan sebuah kebutuhan.

Sukur bumi, mampu memenuhi kebutuhan hidup masyarakatnya.Upacara menjadi ruang ekspresi diri dan kelompok dalam memaknai kehidupan.Secara simbolik, sukur bumi bukan saja sebuah aktivitas sakral, tetapi memiliki kekuatan dalam mengendalikan kehidupan manusia. Sukur bumi memiliki daya dalam mengatur gerak langkah manusia.Ia merupakan ruang cermin diri, tempat berserah diri, tempat belajar tentang kehidupan, memberi petunjuk bagaimana cara hidup. 
Tidak ada yang berbeda dengan cara pemerintah dalam memaknai sukur bumi. Rekonstruksi yang dilakukan adalah jalan melanggengkan posisi kuasanya.Sukur bumi telah menjadi media yang paling aktif dalam melegitimasi kekuasaanya. Karena juga melalui sukur bumi, ia mampu mendapatkan keuntungan secara ekonomi politik. Inilah bentuk atau cara yang dilakukan oleh pemerintah untuk hidupnya, dalam dunianya.

Dalam hal ini sukur bumi menunjukkan kuasanya. Baik masyarakat maupun pemerintah, secara nyata memaknai sukur bumi sebagai proses menjalani kehidupan. Tanpa sukur bumi, makna ataupun kepentingan tersebut tidak ada. Artinya pemerintah dan masyarakat dengan sendirinya memiliki ketergantungan pada sukur bumi.Tidak ada relasi kuasa, tidak ada makna, dan tidak ada kebenaran yang dikonstruksi, jika tidak ada sukur bumi. Dalam konteks inilah, menempatkan sukur bumi sebagai kendali dalam kehidupan. Sukur bumi memiliki kekuatan dalam mengontrol dan mengendalikan hidup manusia, semua tunduk dan patuh.

Ciri khas utama manusia, bukan kodrat fisik atau metafisik-melainkan karyanya, yang menentukan dan membatasi dunia kemanusiaan.Bahasa, mitos, religi, kesenian, dan sejarah adalah sektor-sektor penting (Cassirer, 1990:104).Salah satu karya terbesar manusia adalah sukur bumi, yang didalamnya melekat unsur bahasa, mitos, religi, kesenian, sejarah, sistem kekeluargaan dan mata pencaharian, yang mengikat gagasan tentang sistem kehidupan yang dipilih. Jika bentuk-bentuk kultur terartikulasi dalam berbagai macam artefak (CliffordGeertz, 1992: 21), maka sukur bumi, merupakan artefak yang menyimpan jejak budaya masa lalu dan kini. Karena sukur bumi sebagai artefak yang dinamis, bukan benda mati, ia terus bergerak menuju masa depannya seiring dengan dinamisasi masyarakatnya. Rekonstruksi upacara ngalaksa merupakan salah satu model yang merepresentasikan kehidupan sosial yang terus berkembang. Upacara pun mengalami proses adaptasi bersama perubahan tersebut. Secara bersamaan upacaramenjadi wadah yang demokratis dalam mewariskan nilainilai, sekaligus memiliki instrumen untuk memperbaharui sistem nilai tersebut secara terus menerus.

\section{SIMPULAN}

Dalam reproduksi dan rekonstruksi sukur bumi terdapat tiga level atau tingkatan relasi kuasa.Pertama pada reproduksi, masyarakat memposisikan diri sebagai pihak yang memiliki kuasa dalam memaknai upacara dikaitkan dengan kehidupannya kini.Ia memposisikan diri sebagai pewaris yang pasif, dalam artian tidak mengkritisi atau secara aktif menelusuri makna otentik dari simbol-simbol yang melekat pada upacara. Kepemilikan sebagai pewaris berdasarkan garis keturunan dijadikan oleh masyarakat sebagai modal negosiasi dengan pemerintah dalam melakukan rekonstruksi terhadap sukur bumi.Kedua, pada rekonstruksi, relasi kuasa antara pemerintah dan masayarakat.Dalam model kekuasaan simbolik pemerintah memiliki ruang lebih luas dalam melanggengkan kuasanya, namun demikian masyarakat memiliki modal negosiasi, sehingga secara aktif dapat terlibat dalam pelaksanaan rekonstruksi, karena pemerintah sendiri tidak bisa menjalankan kuasanya tanpa ada masyarakat dan lebih spesifik tanpa ada upacara.Ini menuju pada relasi yang ketiga, yakni masyarakat maupun pemerintah berusaha memperbutkan posisi kekuasan dalam sukur bumi, tetapi dibalik ini semua, sukur bumi memiliki kuasanya sendiri dalam mengendalikan dan mengatur masyarakat maupun pemerintah.Tanpa sukur bumi keduanya tidak memiliki ruang dalam mengkonstruksikan kekuasaanya. Simbol dan unsur-unsur yang terdapat dalam sukur bumi memiliki kekuasaannya sendiri. 


\section{DAFTAR PUSTAKA}

Addullah, Irwan. 2009. Konstruksi dan Reproduksi Kebudayaan. Yogyakarta: Pustaka Pelajar.

Anderson, Benedict R. O'G. 1990. Language and Power: Exploring Political Cultures in Indonesia. Ithaca and London: Cornell University Press.

Barker, Chris. 2008. Cultural Studies: Teori dan Praktik. Yogyakarta: Kreasi Wacana.

Bourdieu, Pierre. 1989. Social Space and Symbolic Power. Journal Sociological Theory, Vol. 7, No. 1, 14-25. American Sociological Association. 1991.Language and Symbolic Power. Cambridge: Polity Press

Cassirer, Ernst. 1987. Manusia dan Kebudayaan: Sebuah Esai tentang Manusia. Jakarta: Gramedia.

Dreyfus, Hubert L, dkk. 1982. Michel Foucault: Beyond Structuralism and Hermeneutics. Chicago: The University of Chicago Press.

Faubion, James D. 2001. Ed. PowerEssential Works of Foucault, 1954-1984. New York: The New Press.

Foucault, Michel. 1965. The Discourse on Language. Dalam HazardAdams and Leroy Searle. Theory Since 1965. Tallahassee: Florida State University Press.
1980. Power/Knowledge: Selected Interviews and other writings 19721977 New York: Pantheon Books.

Geertz, Clifford. 1992. Tafsir Kebudayaan. Yogyakarta: Kanisius.

Martin, Roderick. 1990. Sosiologi Kekuasaan. Jakarta: Rajawali Press.

Walker, J. H. 2004. Autonomy Diversity, and Dissent: Conceptions of Power and Sources of Action in the Sejarah Melayu (Raffles MS, 18). Journal Theory and Society 33: 213-255. Netherlands: Kluwer Academic Publishers.

\section{Nara Sumber:}

1. Karmita, saehu pameget dari rurukanDusun Cibulakan, Desa Pasir Biru, Kecamatan Rancakalong.

2. Mak Ukus (alm), canoli dari Dusun Cikondang, Desa PamerkaranKecamatan Rancakalong

3. Pupung pemain tarawangsa dari Desa Rancakalong

4. Tata, pemain jentreng dari Dusun Cikondang, Desa PamerkaranKecamatan Rancakalong

5. H. Y. Karyono, S.Sos, M.Si, Camat Rancakalong, yang bertugas pada saat penulis melakukan wawancara (tahun 2011) 